\title{
Light absorption properties of CDOM in the Changjiang (Yangtze) estuarine and coastal waters: an alternative approach for DOC estimation
}

Xiaolong $\mathrm{Yu}^{1,2}$, Fang Shen ${ }^{1 *}$, Yangyang $\mathrm{Liu}^{1}$

${ }^{1}$ State Key Laboratory of Estuarine and Coastal Research, East China Normal University, Shanghai 200062, China

${ }^{2}$ Department of Water Resources, Faculty of Geo-Information Science and Earth Observation (ITC), University of Twente, P.O. Box 217, 7500AE Enschede, The Netherlands

*Corresponding author. E-mail address: fshen@sklec.ecnu.edu.cn (F. Shen)

\begin{abstract}
Field measurements of CDOM absorption properties and DOC concentrations were collected in the Changjiang estuarine and coastal waters from 2011 to 2013. CDOM absorption coefficient at 355 $\mathrm{nm}\left(a_{g}(355)\right)$ was found to be inversely correlated with salinity, with Pearson's coefficients $r$ of -0.901 and -0.826 for summer and winter observations, respectively. Analysis results of the relationships between salinity and CDOM optical properties (i.e., absorption coefficient and spectral slope) suggested that terrigenous inputs dominated CDOM sources in the Changjiang estuary, but the proportion of terrigenous CDOM declined with increasing salinity. The level of CDOM in the Changjiang estuary was lower compared to some of the major estuaries in the world, which could be attributed to several controlling factors such as vegetation cover in the drainage basin, the origin of recharged streams and high sediment load in the Changiiang estuary. We further evaluated the relationships between CDOM and DOC and their mixing behavior among world's major estuaries. An empirical model was finally developed to estimate DOC concentration from $a_{g}(355)$ and spectral slope $S_{275-295}$ using a non-linear
\end{abstract}


regression. This empirical relationship was calibrated using the Cal dataset, and was validated with the Val dataset, resulting in an acceptable error with the $R^{2}$ of 0.746 , the RMSE of $20.99 \mu \mathrm{mol} / \mathrm{L}$ and the rMAD of $14.46 \%$.

Keywords: Light absorption; CDOM; DOC; Salinity; the Changjiang (Yangtze) estuary

\section{Introduction}

Colored dissolved organic matter (CDOM) is an important component of coastal waters, controlling the functioning of ecological processes and biogeochemical cycles of marine ecosystems. Light absorption by CDOM mainly depends on the origin of CDOM. Terrestrial sources contain more humic acid and large molecules of dissolved organic matter (DOM), while aquatic sources contain more fulvic acid and smaller DOM molecules (Helms et al. 2008). Riverine discharge is considered as the main source of CDOM in most coastal waters, resulting in a robust correlation between salinity and the CDOM absorption coefficient (Fichot and Benner 2011; Granskog 2012; Xie et al. 2012). The aquatic CDOM is mainly produced locally by phytoplankton degradation and bacterial decomposition. The absorption spectrum of CDOM follows an exponential function, whereby the CDOM absorption decreases with increasing wavelength (Bricaud et al. 1981). The rate of this decrease, hereafter called the spectral slope $\left(S\right.$, in $\left.\mathrm{nm}^{-1}\right)$, can easily be computed from the absorption spectrum of CDOM. This spectral slope is related to the ratio of fulvic to humic acids and the molecular weight (MW) of fulvic acids and is, therefore, commonly used to identify the origins of CDOM (Carder et al. 1989; Keith et al. 2002). The slope $S$ can be computed from the spectral range either using narrow waveband (e.g., 275-295 nm) or broader waveband (e.g., 250-700 nm). However, $S$ computed from narrow waveband is known to be more sensitive to CDOM sources than the $S$ determined from a broader waveband (Asmala et al. 2012; Fichot and Benner 2011, 2012). 
Dissolved organic carbon (DOC), on the other hand, represents $97 \%$ of the organic carbon in the ocean (Hansell and Carlson 1998), and is therefore an essential part in the global carbon cycle. Phytoplankton converts inorganic carbon to organic carbon through photosynthesis (Longhurst and Harrison 1989), contributing a substantial source of DOC in the oceans. Other sources of DOC in the oceans mostly come from riverine discharge and zooplankton activity (Kuliński and Pempkowiak 2008).Terrigenous DOC from river discharges contributes a large portion of DOC in the coastal oceans and is further transported to the open ocean. To understand the migration of terrigenous DOC and estimate the DOC budget from rivers to the ocean, measurements of DOC concentrations are necessary in the coastal oceans. However, traditional DOC measurements are always limited due to discrete sampling. Therefore, a prompt and continuous estimation from earth observation data at large spatial scales would be strongly recommended (Liu et al. 2013; Mannino et al. 2008).

CDOM is the optically active component of DOM and therefore can be potentially linked to DOC concentration. Although CDOM only represents a portion of the entire DOC pool, optical properties of CDOM have been found to be empirically related to DOC concentration in some estuarine and coastal waters (Asmala et al. 2012; Ferrari 2000; Fichot and Benner 2011, 2012; Matsuoka et al. 2012a; Rochelle-Newall et al. 2014; Spencer et al. 2007). For example, DOC concentration can be linked to the CDOM absorption coefficient at a reference wavelength (e.g., $250 \mathrm{~nm}$ or $350 \mathrm{~nm})$ by single linear regression (Baker and Spencer 2004; Matsuoka et al. 2012a; Spencer et al. 2009a). However, linear models rely heavily on the conservative mixing of DOC and CDOM and are not always practical in the coastal waters, such as in the Mississippi River estuary (Chen and Gardner 2004), the Pearl River estuary (Chen et al. 2004) and West Florida Shelf (Del Castillo et al. 2000). The other approach is to estimate DOC from the spectral slope $S_{275-295}$ and the DOC-normalized CDOM absorption coefficient by nonlinear regression (Fichot and Benner 2012). The non-linear model is supposed to be more suitable for coastal waters, especially for river-influenced coastal waters with lignin as the important chromophore of the CDOM pool and the main terrigenous component of DOC (Fichot and Benner 2012). 
The hydrodynamic environment is unique in the Changiiang estuarine and coastal waters due to the joint influences of runoffs, tides and coastal circulations, which makes the mixing behavior between DOC and CDOM more complicated and variable at seasonal and regional scales. For example, conservative mixing behavior was observed in the Changiiang estuary with the DOC concentration linearly related to the CDOM absorption coefficient (Liu et al. 2013; Liu et al. 2014; Zhang et al. 2013). However, the linear correlation was not always practical in this region (Cauwet and Mackenzie 1993; Liu et al. 2013), and could be easily collapsed in the zones with significant phytoplankton production (Liu et al. 2013; Liu et al. 2014). Therefore, field investigations are still necessary to better understand the variation of CDOM and DOC in the Changjiang estuarine and coastal waters. Moreover, an alternative model estimating the DOC concentration could be also useful especially when no correlation between CDOM and DOC concentration can be found.

In this study, we first investigate the seasonal and spatial variations of the CDOM optical properties, which were less well documented in the Changjiang estuarine and coastal waters. We further discuss the potential sources of CDOM and DOC, and employ a non-linear model to estimate the DOC concentration from CDOM optical properties. The developed relationship was found to be robust, and therefore could be an alternative approach to estimate the DOC concentration at large spatial scales from remotely retrieved CDOM optical properties in the Changjiang estuarine and coastal waters.

\section{Materials and methods}

\subsection{Shipborne sampling and measurements}

Water samples were collected during five cruises in the Changjiang estuarine and coastal waters from 2011 to 2013, and the sampling stations are presented in Fig. 1. The field campaigns were carried out in July 2011 (32 samples), July 2012 (29 samples), August 2013 (53 samples), February 2012 (37 samples) and March 2012 (24 samples). A total number of 175 water samples were collected from the surface layer and analyzed for their content of CDOM. Salinity (in PSU, practical salinity units) was recorded 
synchronously to CDOM sampling during the cruises using the CTD device (SeaBird Electronics INC). Note, however, that the salinities of 4 samples (out of 175) were not recorded during the CDOM sampling. DOC samples were collected simultaneously with surface CDOM samples in July of 2011 (31 samples) and August 2013 (53 samples). To investigate the vertical variation of CDOM, depth profile of CDOM was recorded during the cruise in July 2011, whereby CDOM samples were collected at two depths of $5 \mathrm{~m}$ (31 samples) and $10 \mathrm{~m}$ (29 samples).

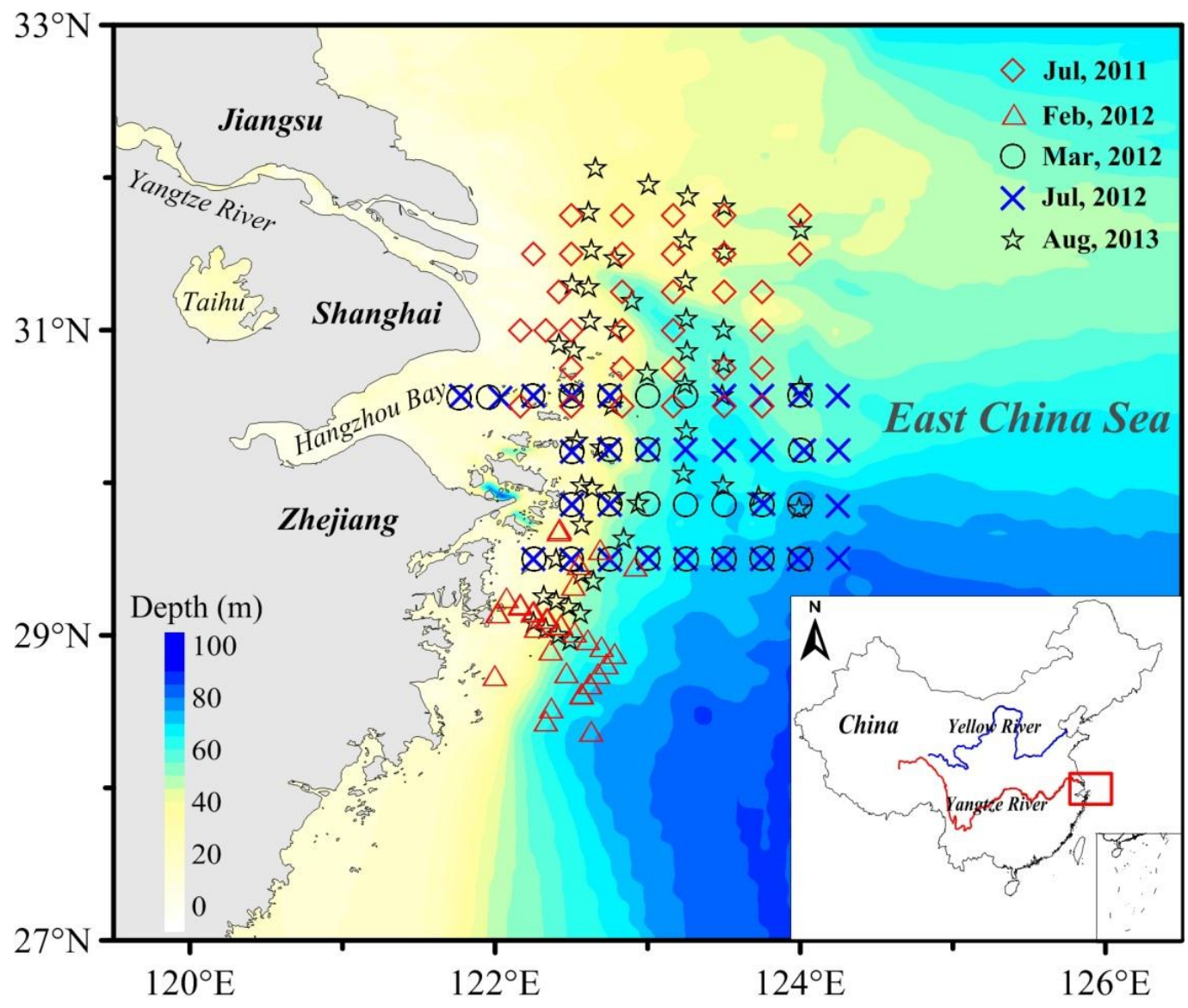

Fig. 1. Location of sampling stations in the Changjiang estuarine and coastal waters. Samples were collected from five cruises in summer (July 2011, July 2012 and August 2013) and winter (February and March of 2012).

Water samples were gravity-filtered on shipboard using a $0.22 \mu \mathrm{m}$ polycarbonate membrane (Millipore, $47 \mathrm{~mm}$ diameter) under low vacuum immediately after the sampling. The membranes were soaked in $10 \%$ HCL for 15 mins and then rinsed by Milli-Q water three times before the filtration. The filtered CDOM samples were collected in borosilicate glass vials, and then stored in the $-40^{\circ} \mathrm{C}$ 
refrigerator. All vials were pre-soaked in $10 \% \mathrm{HCL}$ for $24 \mathrm{~h}$, rinsed by Milli-Q water for three times, and pre-combusted at $450^{\circ} \mathrm{C}$ for $5 \mathrm{~h}$. DOC samples were filtered using a $0.45 \mu \mathrm{m}$ nylon membrane (RephiLe RF-Jet Syringe Filter, $25 \mathrm{~mm}$ diameter) and collected in ampoule bottles, which were pre-combusted at $500^{\circ} \mathrm{C}$ for $5 \mathrm{~h}$. After the filtration, the ampoule bottles were sealed by fusing the bottleneck, and then stored in the $-40^{\circ} \mathrm{C}$ refrigerator.

\subsection{Laboratory measurements}

Immediately prior to measurement, CDOM samples were unfrozen and warmed to room temperature under fully dark conditions, which was used to minimize the freezing influence on the absorption spectra. The CDOM absorbance spectra were measured from 250 to $900 \mathrm{~nm}$ using a $10 \mathrm{~cm}$ quartz cuvette referenced to the Milli-Q water by the PerkinElmer Lambda 1050 UV/VIS spectrophotometer. The

CDOM absorption coefficient $a_{g}^{\prime}(\lambda)$ (in $\mathrm{m}^{-1}$ ) was then computed from the absorptance $D(\lambda)$ as (Pegau et al. 1997):

$a_{g}^{\prime}(\lambda)=2.303 \times D(\lambda) / l$

where, $l$ is the cuvette path length. The effect of scattering was corrected by normalizing the spectra to zero at $700 \mathrm{~nm}$ (Bricaud et al. 1981),

$a_{g}(\lambda)=a_{g}^{\prime}(\lambda)-a_{g}^{\prime}\left(\lambda_{700}\right) \times \lambda / \lambda_{700}$

where, $\lambda_{700}$ is the $700 \mathrm{~nm}$ wavelength and $a_{g}(\lambda)$ is the CDOM absorption coefficient after the scattering correction. Fig. 2 shows the absorption spectra of all CDOM samples. 


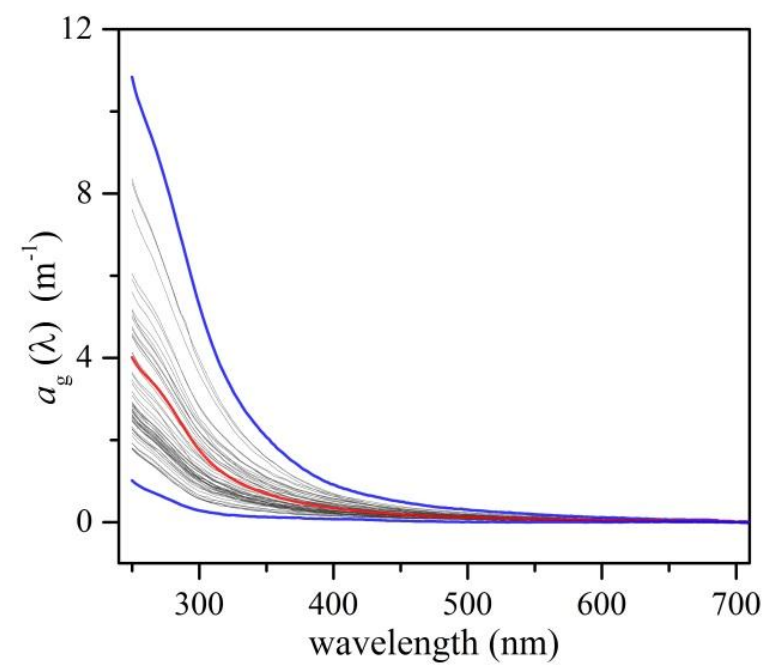

Fig. 2. CDOM absorption spectra of all measurements. The two blue spectra represent samples with maximum and minimum absorption coefficients, while the red spectrum represents the mean absorption coefficient of all samples.

The spectral slope is derived from CDOM absorption spectra by fitting the absorption data to the exponential equation (i.e., Eq. (3)) using the optimization method (Bricaud et al. 1981),

$a_{g}(\lambda)=a_{g}\left(\lambda_{0}\right) e^{-S\left(\lambda-\lambda_{0}\right)}$

where, $\lambda$ is wavelength $(\mathrm{nm})$ and $\lambda_{0}$ is the reference wavelength $(\mathrm{nm})$. As shown in Fig. $2, S$ is apparently dependent on the wavelength interval over which it is calculated. We chose $440 \mathrm{~nm}$ as the reference wavelength to calculate the spectral slope for the broad range from 250 and $700 \mathrm{~nm}$, which is hereafter denoted as $S_{440} . S_{275-295}$ and $S_{350-400}$ were also calculated for the narrow wavelength intervals from 275 to $295 \mathrm{~nm}$ and 350 to $400 \mathrm{~nm}$, respectively. The spectral slope ratio $S_{\mathrm{R}}$ was then defined as the ratio of $S_{275-}$ 295 and $S_{350-400 .}$

DOC concentration (in $\mu \mathrm{mol} / \mathrm{L}$ ) was determined in duplicate with a Shimadzu TOC-VCPH Total Organic Carbon analyzer using potassium hydrogen phthalate as the standard for the DOC calibration curve. The typical precision of this instrument is less than $2 \%$ in terms of the coefficient of variation. DOC samples were acidified by $100 \mu \mathrm{L} 2 \mu \mathrm{mol} / \mathrm{L}$ phosphoric acid prior to the measurement to remove the inorganic carbon. To ensure the accuracy and consistency of measured DOC concentration, we analyzed the Florida Strait seawater reference, provided by Dr. Hansell's laboratory at the University of 
Miami, at the beginning and every fifth sample. The average measured DOC concentration of the Florida Strait seawater was $45.6 \mu \mathrm{mol} / \mathrm{L}$, which fitted well to the expected range (44 - $46 \mu \mathrm{mol} / \mathrm{L})$. DOC concentrations were estimated as the average value of the duplicate measurements. The DOC-normalized

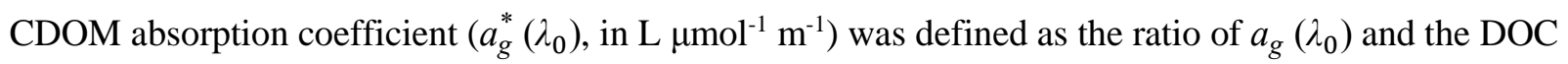
concentration.

\subsection{Data analysis}

To evaluate the relationship between salinity and CDOM absorption, we calculate the Pearson's coefficient $r$ and the probability $p$ of the linear regression. For the goodness-of-fit between derived and known DOC concentration, statistical parameters such as the determination coefficient $R^{2}$, the mean of absolute relative difference (rMAD) and the root mean square error (RMSE) are determined. The rMAD and the RMSE are defined as follows:

$\mathrm{rMAD}=\sum \mid 1-$ derived $/$ known $\mid / \mathrm{N} \times 100 \%$,

RMSE $=\sqrt{\sum(\text { derived }- \text { known })^{2} / \mathrm{N}}$,

where, $\mathrm{N}$ is the number of observations.

\section{Results}

\subsection{Spatial-temporal variation of CDOM}

The distribution of the CDOM absorption coefficient $\left(a_{g}(355)\right)$ at the surface layer in the Changjiang estuarine and coastal waters is presented in Fig. 3, where noticeable spatial-temporal variations of $a_{g}(355)$ can be observed. 

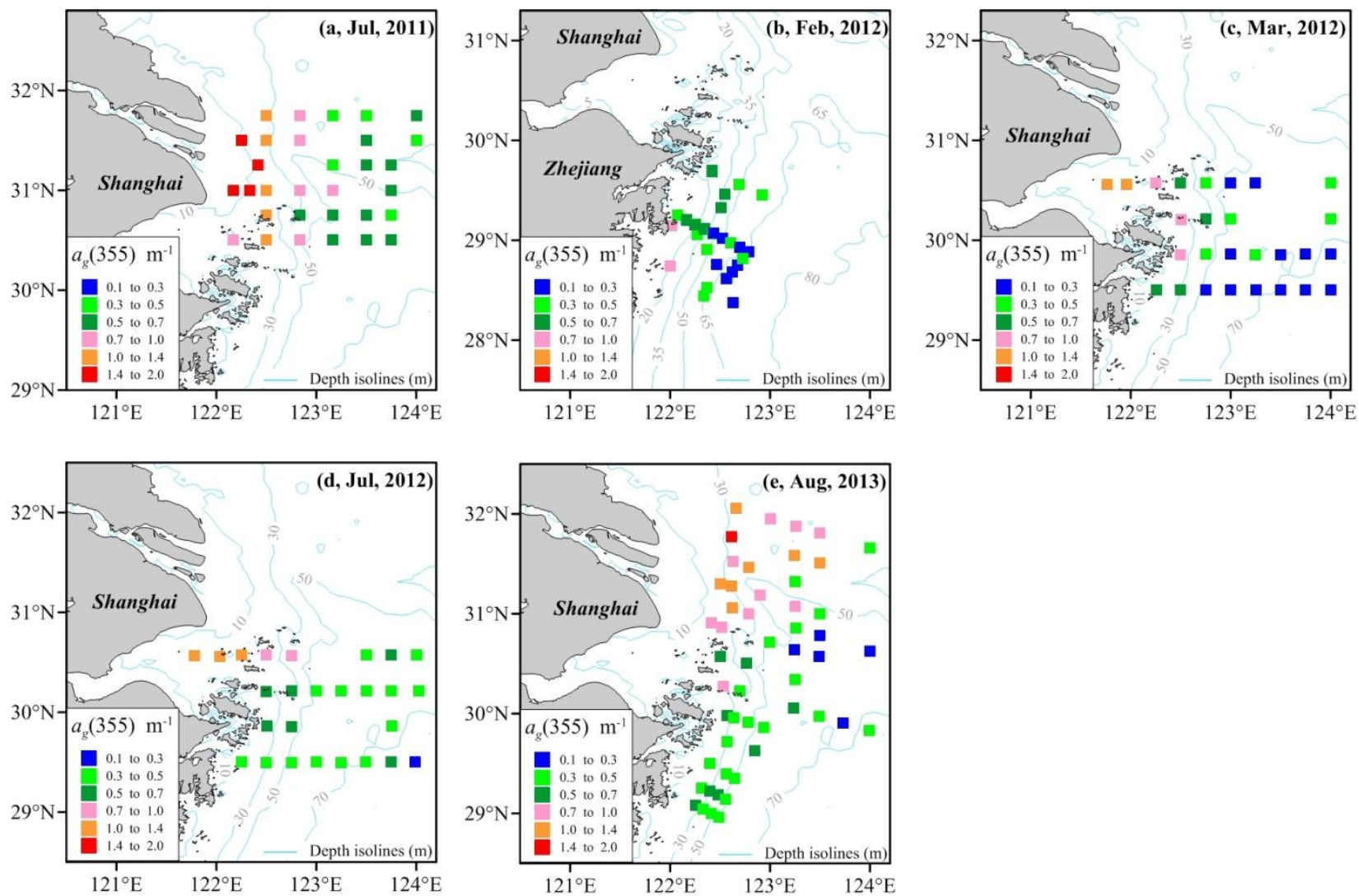

Fig. 3. Spatial distribution of surface $a_{g}$ (355) over the Changiiang estuarine and coastal region. Data was collected from five cruises in July of 2011 (a), February (b), March (c), July (d) of 2012 and August of 2013 (e).

The $a_{g}(355)$ values ranged from 0.42 to $1.91 \mathrm{~m}^{-1}$ in July 2011, from 0.11 to $0.84 \mathrm{~m}^{-1}$ in February 2012, from 0.13 to $1.21 \mathrm{~m}^{-1}$ in March 2012, from 0.26 to $1.36 \mathrm{~m}^{-1}$ in July 2012 and from 0.23 to $1.45 \mathrm{~m}^{-1}$ in August 2013, respectively. The $a_{g}(355)$ values exhibited a gradual decrease from nearshore to offshore, forming a persistent northwest-southeast gradient, with low values (less than $0.5 \mathrm{~m}^{-1}$ ) in regions far from the river mouth. Most samples in March and July 2012 were collected at the same sites (Figs. 3c and 3d), from which we can observe that CDOM absorption coefficients in summer were higher than in winter. The annual variation of $a_{g}$ (355) over the study area in the summer from 2011 to 2013 is also observed according to Figs. 3a, 3d and 3e. The average values of $a_{g}(355)$ are $0.89 \mathrm{~m}^{-1}, 0.52 \mathrm{~m}^{-1}$ and $0.60 \mathrm{~m}^{-1}$ in July 2011, July 2012 and August 2013, respectively.

As shown in Fig. 4, the vertical gradients of $a_{g}(355)$ in July 2011 are random among the stations with no consistent depth profile. The largest variations of the $a_{g}(355)$ depth-profile are found at stations 
adjacent to the Changjiang river mouth (e.g., stations with longitudes below $122.5^{\circ} \mathrm{E}$ in Figs. $4 \mathrm{c}, 4 \mathrm{e}$ and 4f), while vertical variations in offshore are rather small, especially for stations with longitudes larger than $123^{\circ} \mathrm{E}$.
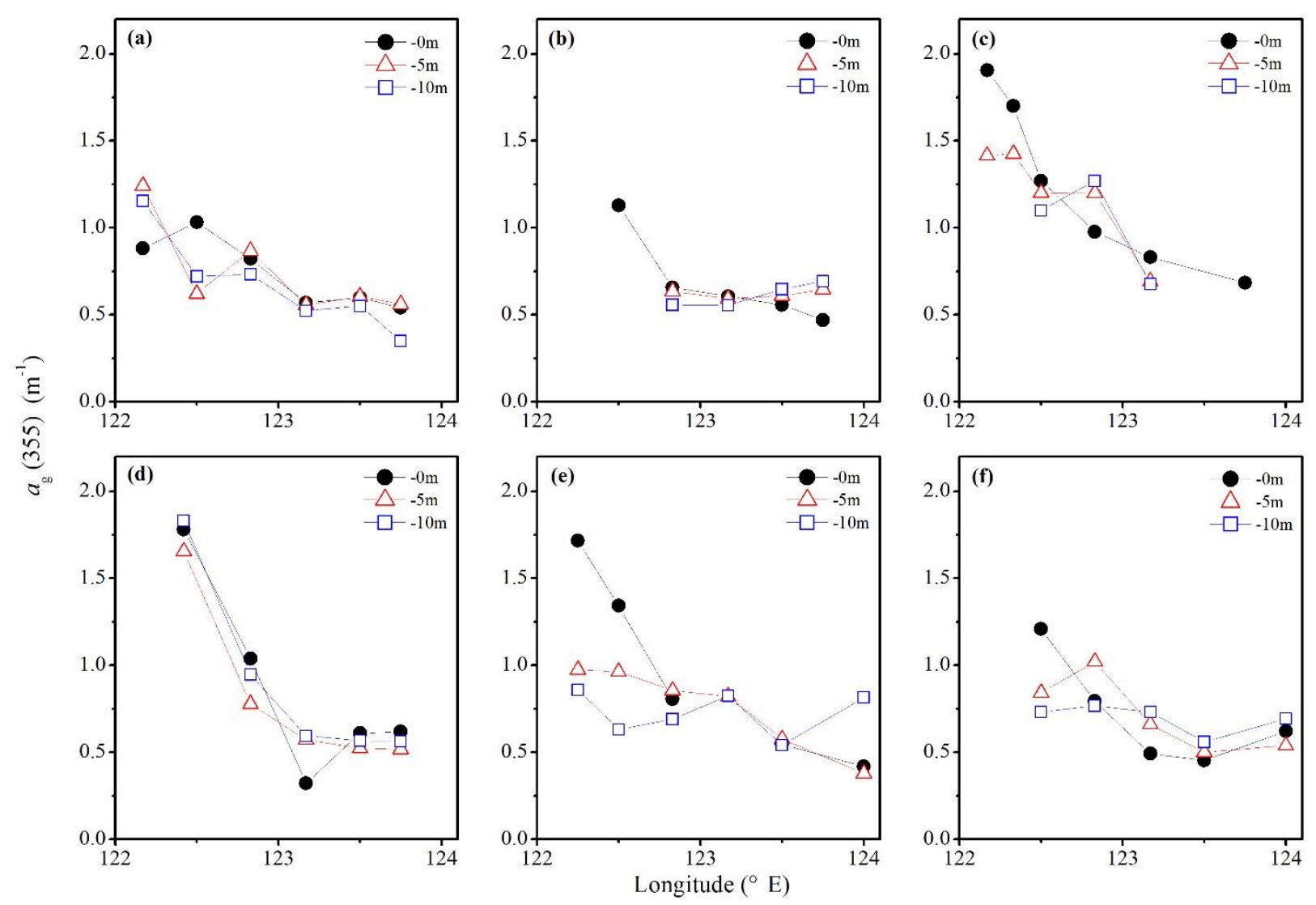

Fig. 4. Vertical distribution of $a_{g}$ (355) along geographic longitude increasing in July 2011. Figs. 4a - 4f are corresponding to the six axial transects in Fig. 3a from the bottom up.

\subsection{CDOM and salinity}

Salinity is a perfect indicator of the influence of river runoff in the estuarine regions. The variation of salinity is mainly attributed to the mixing between fresh river discharge and saline ocean water. Fresh water is almost free from salinity while the surface salinity in the open ocean is typically between 32 and 37 PSU (Lagerloef et al. 1995). To better explore the relationship between the CDOM absorption coefficient and salinity, CDOM measurements are divided into subsets based on two criteria. The first classification is based on the sampling seasons, i.e. winter and summer. The second is according to the 
salinity values, from which three classes are formed using two thresholds of 20 PSU and 32 PSU. We consider that samples with salinity lower than 20 PSU are riverine-dominant while marine-dominant samples have salinities greater than 32 PSU. Fig. 5 shows the relationships between salinities and $a_{g}$ (355), as well as their linear fitting parameters.
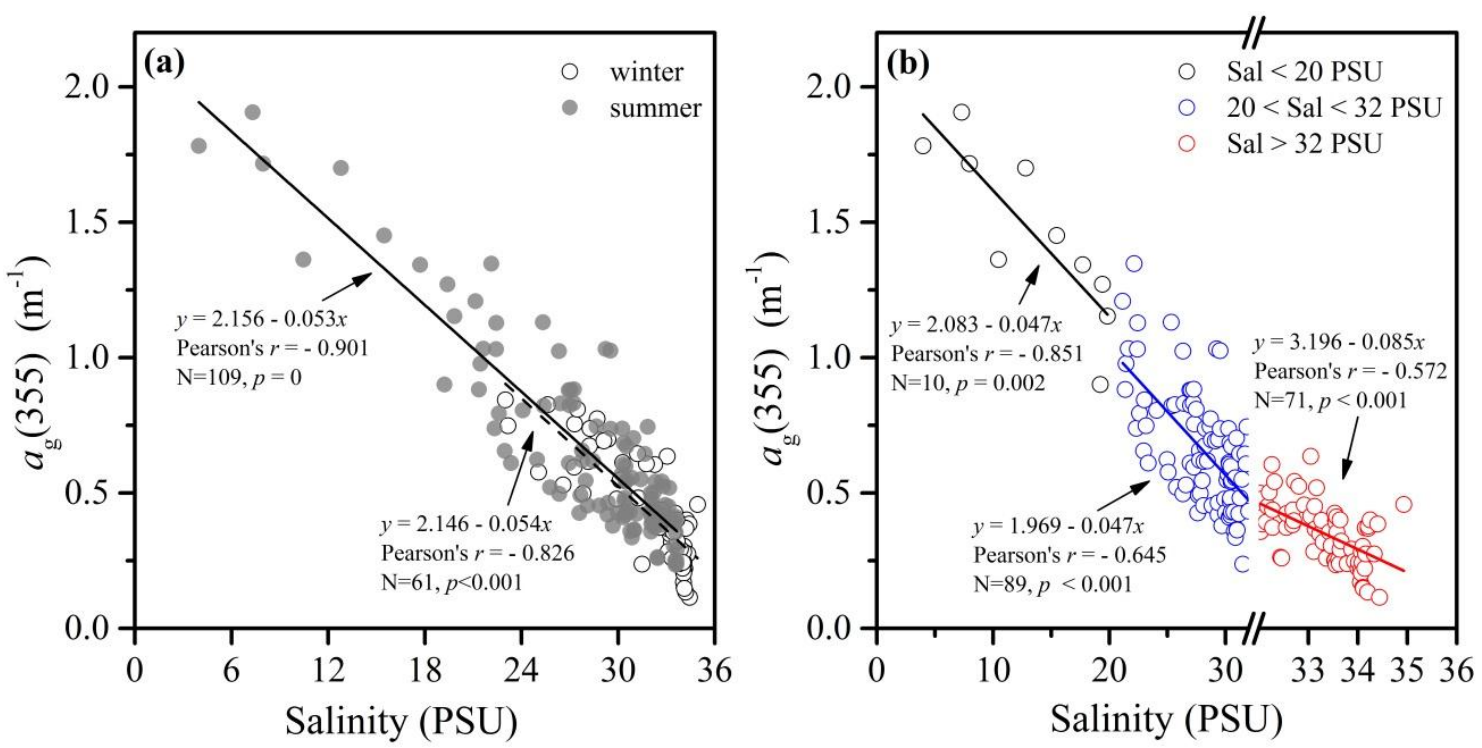

Fig. 5. Relationships between salinity and $a_{g}$ (355). All CDOM measurements are divided into (a) two subsets for samples collected in winter and summer and (b) three subsets according to the salinity values with two thresholds at 20 and 32 PSU.

From Fig. 5a we observe that $a_{g}(355)$ is negatively correlated with salinity, with a more robust correlation in summer $(r=-0.901, p=0)$ than in winter $(r=-0.826, p<0.001)$. Moreover, as shown in Fig. 5b, the correlation is more robust for low salinity samples ( $<20$ PSU, $r=-0.851, p=0.002$ ) compared to high salinity samples ( $>32$ PSU, $r=-0.572, p<0.001$ ).

\subsection{Spectral slope of CDOM absorption and salinity}

The range of $S_{440}$ for all samples was from 0.009 to $0.019 \mathrm{~nm}^{-1}$ with an average value of $0.015 \mathrm{~nm}^{-1}$. Seasonal variations of $S_{440}$ are also observed as the average value of $S_{440}$ in July 2012 was $0.017 \pm 0.001$ $\mathrm{nm}^{-1}$ while the average value in March 2012 was $0.0145 \pm 0.0017 \mathrm{~nm}^{-1}$. On the other hand, $S_{275-295}$ ranges from 0.015 to $0.032 \mathrm{~nm}^{-1}$ for all observations with an average value of $0.021 \mathrm{~nm}^{-1}$. However, opposite to 
the seasonal variation of $S_{440}$, the average value of $S_{275-295}$ in March $2012\left(0.023 \pm 0.004 \mathrm{~nm}^{-1}\right)$ was higher than in July $2012\left(0.018 \pm 0.002 \mathrm{~nm}^{-1}\right)$.

No correlation between $S_{440}$ and salinity can be found in this study (figure not shown), while both $S_{275-}$ 295 and $S_{\mathrm{R}}$ increased with the increasing salinity as shown in Fig. 6 . The patterns between salinity and $S_{275-}$ 295 and $S_{\mathrm{R}}$ are in accordance with previous studies (Fichot and Benner 2012; Helms et al. 2008).

Moreover, the correlation with salinity is more robust in riverine-dominant samples for both $S_{275-295}$ and $S_{\mathrm{R}}$.
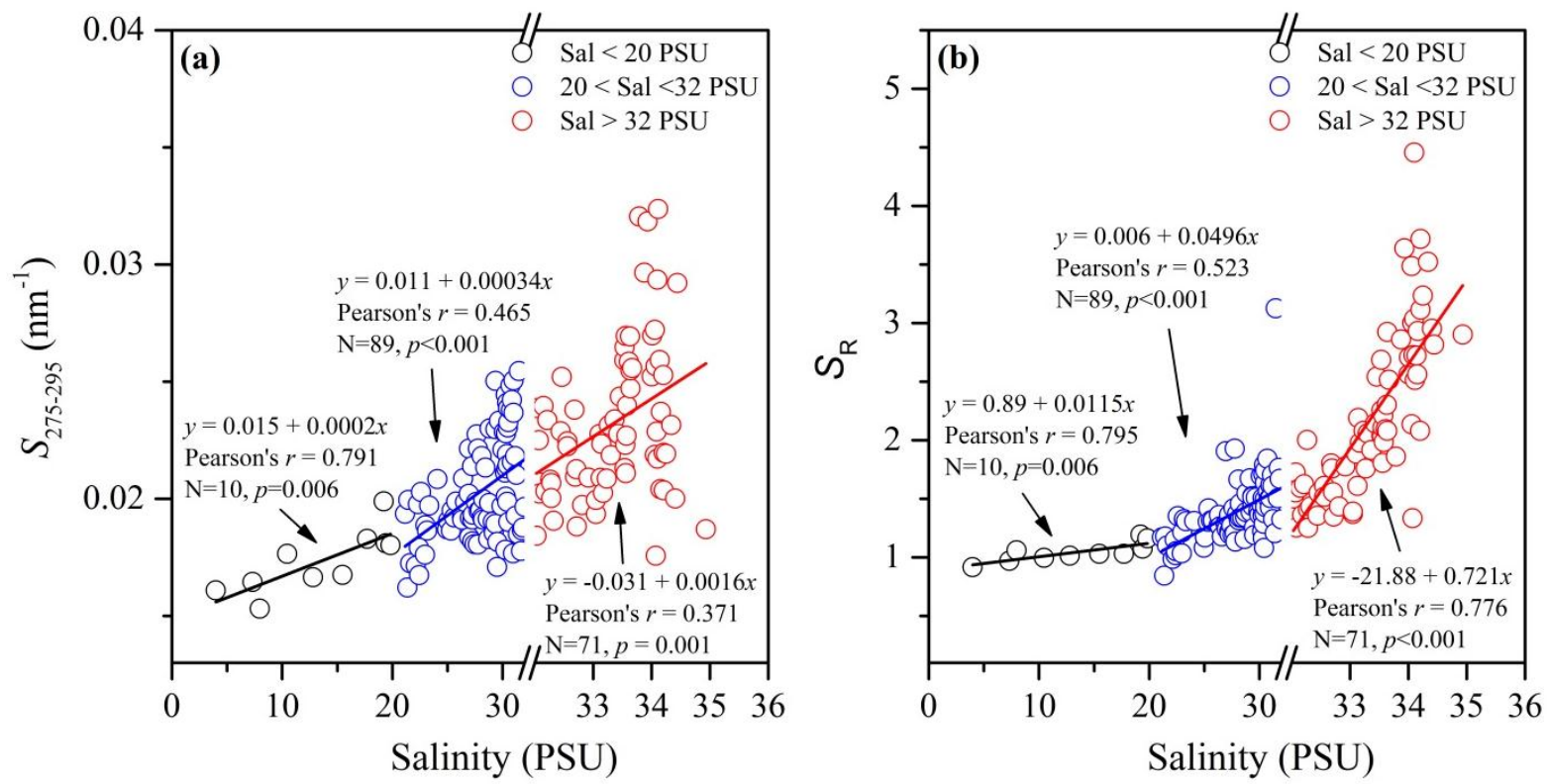

Fig. 6. Scatter plots between salinity and (a) $S_{275-295}$ and (b) $S_{\mathrm{R}}$. All observations are divided into three subsets using thresholds of salinity at 20 PSU and 32 PSU.

\subsection{CDOM properties and DOC}

DOC concentrations ranged from 60.54 to $217.06 \mu \mathrm{mol} / \mathrm{L}$ in this study, with an average value of $115.41 \mu \mathrm{mol} / \mathrm{L}$. DOC was not correlated to both salinity and $a_{g}(355)$ in this study, presenting a nonconservative mixing behavior between CDOM and DOC. To estimate DOC from CDOM properties, we adopted the approach of Fichot and Benner (2012) and developed a non-linear relationship between $S_{275-}$ 295 and DOC-normalized CDOM absorption coefficient. All the DOC samples were divided into two optimal calibration and validation sets according to the GeoCal/Val model of Salama et al. (2012). The 
$\mathrm{Cal}$ and Val sets were selected such that they have the same moments (mean and standard deviation). An exponential function was used to fit $a_{g}^{*}(355)$ and $S_{275-295}$ for the calibration dataset (Fig. 7a), resulting in a $R^{2}$ of 0.78 . The fitting equation is expressed as,

$$
a_{g}^{*}(355)=e^{\left(-2.45-130.79 S_{275-295}\right)}
$$

The fitting equation from Fichot and Benner (2012) is also provided in Fig. 7a for reference. The developed model was applied to the Val dataset to estimate the error of retrieved DOC as shown in Fig. 7b. The accuracy of our model in Eq. (6) is expressed by the $R^{2}$ of 0.746 , the RMSE of $20.99 \mu \mathrm{mol} / \mathrm{L}$ and the rMAD of $14.46 \%$.
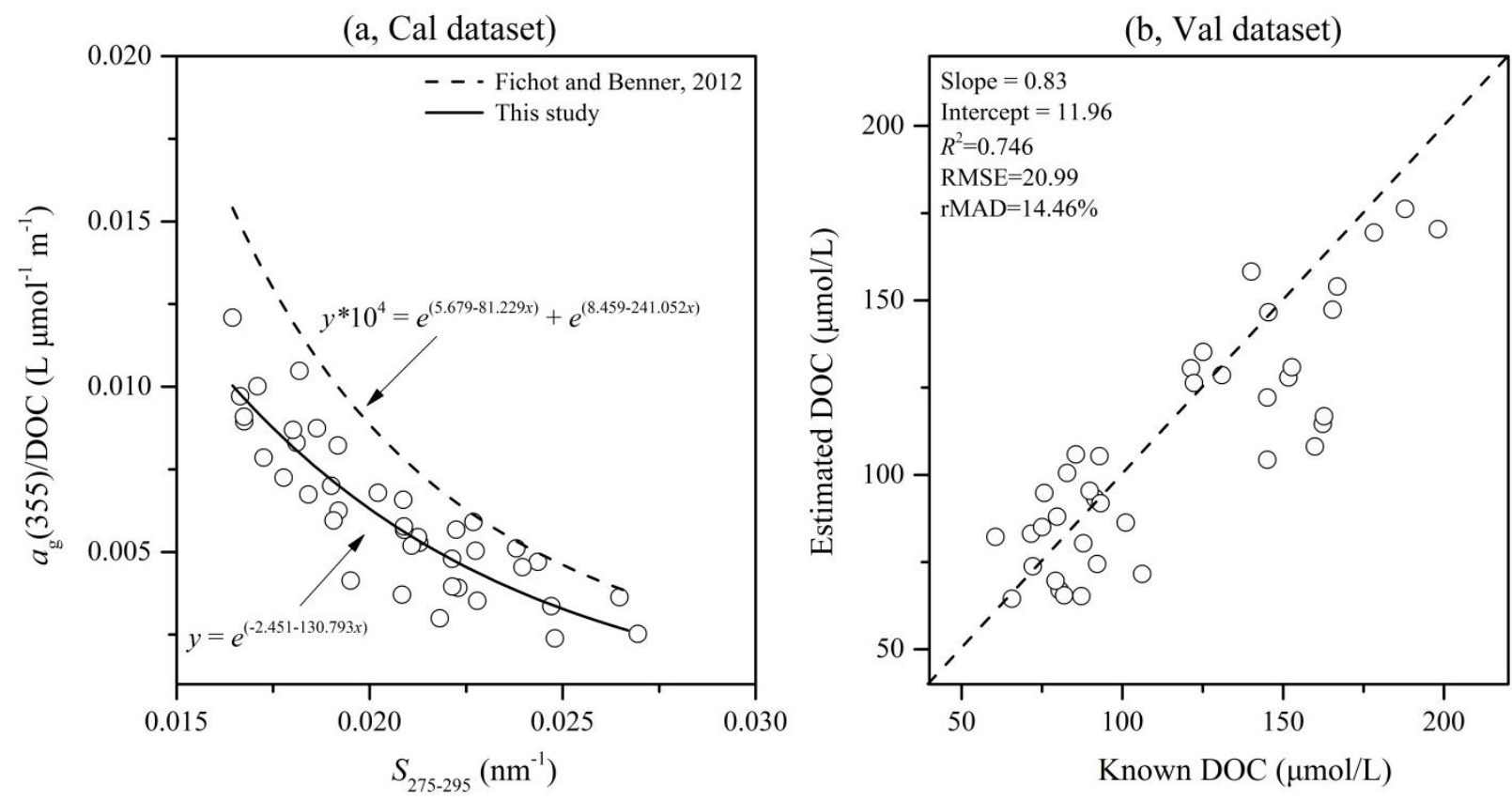

Fig. 7. Calibration and validation for DOC estimation model using the $\mathrm{Cal}$ and Val datasets. (a) A non-linear relationship (black line) is used to fit $a_{g}^{*}(355)$ and $S_{275-295}$ using the Cal dataset. A referential relationship from Fichot and Benner (2012) is also provided (dash line). (b) Validation of the developed model using the Val dataset. 


\section{Discussion}

\subsection{Comparison of CDOM and DOC in several estuarine and coastal waters}

Table 1 shows the comparison of several investigated parameters among the world's estuarine and coastal waters, including the ranges of the CDOM absorption coefficient, spectral slope $S_{440}$, salinity, DOC concentration and the relationship between CDOM and DOC. In general, the level of $a_{g}(355)$ in the Changjiang estuary was on par with the Pearl River estuary, but lower than most of the world's major estuaries, which is consistent with previous studies in the Changjiang estuary and other Chinese estuaries (Guo et al. 2014; Pan et al. 2012).

The abundance of DOM in the estuarine and coastal water is always influenced by vegetation, climate, and the types of rock and soil in the river basins (Ludwig et al. 1996; Pan et al. 2012). As shown by the Terra MODIS NDVI products (http://earthobservatory.nasa.gov/GlobalMaps/view.php?d1=MOD13A2

_M_NDVI), the coverage of vegetation in the Changjiang River basin is lower compared to other drainage basins of the world's major rivers, which is probably due to rapid urbanization and massive deforestation in the past decades (Huang et al. 2015; Huang et al. 2016). The low degree of vegetative cover in the drainage basin could be an important factor in determining the relatively low content of soil organic matter, and therefore results in a low level of CDOM in the Changjiang estuary. The same factor was also reported to be responsible for the low level of CDOM in the Pearl River estuary (Chen et al. 2004; Hong et al. 2005). 
Table 1. Comparisons of CDOM optical properties, salinity, DOC concentration and the relationship between CDOM and DOC among different estuarine and coastal waters.

\begin{tabular}{|c|c|c|c|c|c|c|c|}
\hline Region & $\begin{array}{l}a_{\mathrm{g}}(355) \\
\left(\mathrm{m}^{-1}\right)\end{array}$ & $\begin{array}{l}S_{440} \\
\left(\mathrm{~nm}^{-1}\right)\end{array}$ & $\begin{array}{l}\text { Salinity } \\
\text { (PSU) }\end{array}$ & $\begin{array}{l}\text { DOC } \\
(\mu \mathrm{mol} / \mathrm{L})\end{array}$ & $\begin{array}{l}\text { CDOM } \\
\text { vs. DOC }\end{array}$ & Season & References \\
\hline $\begin{array}{l}\text { Amazon River } \\
\text { and Estuary }\end{array}$ & $0.14 \sim 3.12$ & $0.014 \sim 0.033$ & $0 \sim 36.4$ & $\mathrm{NA}$ & $\mathrm{NA}$ & winter & $\begin{array}{l}\text { (Green and Blough } \\
1994)\end{array}$ \\
\hline $\begin{array}{l}\text { Orinoco River } \\
\text { plume }\end{array}$ & $\begin{array}{l}0.93 \sim 9.02 \\
a_{\mathrm{g}}(300)\end{array}$ & $0.012 \sim 0.022$ & $19.7 \sim 34.6$ & $84 \sim 276$ & Correlated & fall & $\begin{array}{l}\text { (Del Castillo et al. } \\
\text { 1999) }\end{array}$ \\
\hline $\begin{array}{l}\text { St. Lawrence } \\
\text { River Estuary }\end{array}$ & $0.2 \sim 3.8 a_{\mathrm{g}}(365)$ & 0.015 & $0 \sim 35.5$ & NA & NA & summer & (Nieke et al. 1997) \\
\hline $\begin{array}{l}\text { Mackenzie River } \\
\text { Estuary }\end{array}$ & $0.6 \sim 2.02 a_{\mathrm{g}}(320)$ & $\begin{array}{l}0.018 \sim 0.025 \\
S_{320}\end{array}$ & $24.5 \sim 30.1$ & $73.3 \sim 205.8$ & Correlated & fall & $\begin{array}{l}\text { (Retamal et al. } \\
\text { 2007) }\end{array}$ \\
\hline $\begin{array}{l}\text { Southern Beaufort } \\
\text { Sea }\end{array}$ & $\begin{array}{l}0.018 \sim 1.08 \\
a_{\mathrm{g}}(440)\end{array}$ & $0.015 \sim 0.023$ & $0 \sim 35.0$ & $49-460$ & Correlated & summer & $\begin{array}{l}\text { (Matsuoka et al. } \\
\text { 2012a) }\end{array}$ \\
\hline Scheldt Estuary & $\begin{array}{l}0.97 \sim 4.22 a_{\mathrm{g}}(375) \\
2.34 \sim 4.29 \quad a_{\mathrm{g}}(375)\end{array}$ & $\begin{array}{l}0.017 \sim 0.019 \\
0.018 \sim 0.019\end{array}$ & $\begin{array}{l}0.7 \sim 29.6 \\
2.7 \sim 19.9\end{array}$ & $\begin{array}{l}\text { NA } \\
\text { NA }\end{array}$ & $\begin{array}{l}\text { NA } \\
\text { NA }\end{array}$ & $\begin{array}{l}\text { winter } \\
\text { summer }\end{array}$ & $\begin{array}{l}\text { (Astoreca et al. } \\
\text { 2009) }\end{array}$ \\
\hline $\begin{array}{l}\text { Northern Gulf of } \\
\text { Mexico }\end{array}$ & $\begin{array}{l}3.96 \sim 17.52 \\
a_{\mathrm{g}}(350)\end{array}$ & NA & $0 \sim 37$ & $232 \sim 611$ & Correlated & all & $\begin{array}{l}\text { (Fichot and Benner } \\
\text { 2012) }\end{array}$ \\
\hline $\begin{array}{l}\text { Chesapeake Bay } \\
\text { Pearl River estuary }\end{array}$ & $\begin{array}{l}0.4 \sim 4.5 \\
0.24 \sim 1.93\end{array}$ & $\begin{array}{l}0.015 \sim 0.024 \\
0.014 \sim 0.018\end{array}$ & $\begin{array}{l}0 \sim 33 \\
0 \sim 32.5\end{array}$ & $\begin{array}{l}60 \sim 290 \\
\text { NA }\end{array}$ & $\begin{array}{l}\text { Correlated } \\
\text { NA }\end{array}$ & $\begin{array}{l}\text { all } \\
\text { winter }\end{array}$ & $\begin{array}{l}\text { (Rochelle-Newall } \\
\text { and Fisher 2002) } \\
\text { (Hong et al. 2005) }\end{array}$ \\
\hline Pearl River estuary & $0.34 \sim 1.40$ & NA & $0 \sim 35.0$ & $86 \sim 250$ & Uncorrelated & summer & (Chen et al. 2004) \\
\hline $\begin{array}{l}\text { Changjiang } \\
\text { estuary }^{a}\end{array}$ & $0.1 \sim 3.2$ & $0.017 \sim 0.020$ & $0 \sim 32.0$ & NA & NA & summer & (Guo et al. 2007) \\
\hline $\begin{array}{l}\text { Changjiang } \\
\text { estuary }^{\text {a }}\end{array}$ & $0.10 \sim 2.82$ & $0.017 \sim 0.020$ & $0.12 \sim 29.4$ & $41.7 \sim 126.2$ & Correlated & spring & (Sun et al. 2014) \\
\hline $\begin{array}{l}\text { Changjiang } \\
\text { estuary }^{\text {a }}\end{array}$ & $\begin{array}{l}0.43 \sim 3.74 \\
0.05 \sim 1.15\end{array}$ & $\begin{array}{l}0.018 \sim 0.022 \\
0.012 \sim 0.023\end{array}$ & $\begin{array}{l}0.2 \sim 26.5 \\
19 \sim 34.5\end{array}$ & $\begin{array}{l}139.4 \sim 220 \\
63.7 \sim 129.5\end{array}$ & Correlated & $\begin{array}{l}\text { summer } \\
\text { winter }^{\mathrm{b}}\end{array}$ & (Zhang et al. 2013) \\
\hline $\begin{array}{l}\text { Changjiang } \\
\text { estuary }^{c}\end{array}$ & $\begin{array}{l}0.11 \sim 1.20 \\
0.23 \sim 1.91\end{array}$ & $\begin{array}{l}0.008 \sim 0.018 \\
0.012 \sim 0.025\end{array}$ & $\begin{array}{l}18.7 \sim 34.9 \\
4.0 \sim 33.6\end{array}$ & $\begin{array}{l}\text { NA } \\
60.5 \sim 217\end{array}$ & $\begin{array}{l}\text { NA } \\
\text { Uncorrelated }\end{array}$ & $\begin{array}{l}\text { winter } \\
\text { summer }\end{array}$ & This study \\
\hline
\end{tabular}

a) Included samples collected from the river mouth; b) Included data collected from the PN section in March of 2011 in their study; c) Only data from the surface layer is counted; NA means no data or information can be found in their study.

The recharged streams could also have huge impact on the level of CDOM in the river. Compared to streams originated from marshland, peatland and rainforest, streams originated from glacier and mountain areas usually have a low degree of DOM and their discharges into the main river will dilute the concentration of DOM (Pan et al. 2012). The Changjiang River originates from the Tanggula Mountains that are underlain by glaciers in large expanses. Dilution by stream recharged from glacial melting could 
be an important factor in explaining the low concentration of CDOM in the estuary. On the other hand, the Changjiang River has a relatively high sediment load compared to other major rivers in the world with an average annual discharge of 0.39 billion of tons of sediments from 1951 to 2010, (Changjiang Sediment Bulletin of 2012, available in Chinese at http://www.cjh.com.cn/fileupload/2013-0913/130913171010455.pdf). The high load of suspended matter prevents the light from penetrating into the water and limits the photosynthesis of phytoplankton in the upper layer. Therefore, the aquatic sources of CDOM from photosynthesis could be reduced significantly in the estuarine waters.

\subsection{Spatial-temporal variation of CDOM in the Changjiang estuary}

The northwest-southeast gradient of decreasing CDOM observed in this study could be attributed to the mixing of freshwater and seawater. The freshwater end-member contains much higher CDOM than seawater in the Changjiang estuary as shown in this study as well as in Guo et al. (2014). However, the influence of the Changjiang's runoff weakens with the increasing distance from the river mouth, resulting in the observed gradient. This kind of spatial distribution is in accordance with previous studies in this area (Lei et al. 2012; Sun et al. 2014), and was also observed in other river-influenced estuaries such as the St. Lawrence Estuary (Nieke et al. 1997), the Southern Bight of the North Sea (Warnock et al. 1999) and two estuaries of Canadian Arctic (Retamal et al. 2007). Note that the spatial distribution of CDOM in February 2012 (Fig. 3b) did not follow this gradient. A more likely explanation could be that the samples were collected during a tidal cycle. The tide type in the Hangzhou Bay and adjacent waters is semidiurnal and the sampling interval in the February cruise was less than 1 hour. Therefore, CDOM variability could be affected by the resuspension of bottom sediments during the reverse phase of the tide. During the resuspension, bottom sediments with terrestrial matter are injected into overlying waters and thus increase the CDOM concentration (Bodineau et al. 1998).

The seasonal difference in CDOM, between March 2012 (Fig. 3c) and July 2012 (Fig. 3d), was mainly because of the changes in the Changjiang's runoff, which was almost doubled from March to July in 2012 (See also the Changjiang Sediment Bulletin of 2012), resulting in a higher level of CDOM in summer. In 
addition, due to the weak freshwater input in winter, tidal movement could be dominant in the coastal region, resulting in the low level of CDOM (Guo et al., 2014). However, the seasonal variation of CDOM was not obvious for the two stations in the Hangzhou bay (Fig. 3c and Fig. 3d), presenting a relatively stable level of CDOM in the Hangzhou Bay. In the turbid waters like the Hangzhou Bay, the observed seasonal variation of CDOM level could be the affected and balanced by several factors, such as CDOM could be removed by flocculation and particle sorption, added by particle desorption and degradation of particulate organic matter (POM), or released from interstitial water enriched with CDOM by resuspension (Guo et al., 2014). It is worthy to notice that sediment resuspension in the Hangzhou Bay is significant in winter due to the distinct structure of the bay and the mutual effects by wind and tide Chen et al. (2003).

The vertical distribution of $a_{g}(355)$ was more stratified in coastal waters and peaked in the surface layer, which might be due to hydrological dynamics and the mixing behavior between fresh river discharge and saline ocean water. Similar phenomena were also observed in other estuarine regions (Del Castillo and Miller 2011; Gardner et al. 2005). The stratification was not significant in most offshore stations, which can be explained by the weak influence of the runoff.

Comparing with reported results from Guo et al. (2007) and Zhang et al. (2013), the interannual variation of $a_{g}(355)$ in the summer are in general small in the estuarine and coastal waters. Note that the tabulated data in Table 1 for the results from Guo et al. (2007) and Zhang et al. (2013) included samples collected in the river's mouth with high absorption. The limited interannual variation of CDOM indicates that parameterization of CDOM absorption coefficient could adopt the locally defined parameters (e.g., average $a_{g}(355)$ and $\left.S_{400}\right)$ in reducing the uncertainties of the retrieval models on inherent optical properties (IOPs). This is mainly because CDOM contributes a large portion to the total absorption coefficient in most estuaries, and is therefore sensitive in IOPs-retrieval models (Garver and Siegel 1997; Lee et al. 2007; Lee et al. 2002; Maritorena et al. 2002; Yang et al. 2013; Yu et al. 2016). However, 
CDOM parameterization (Eq. (3)) in these models always requires an empirical coefficient (e.g., $\left.S_{440}\right)$ and a locally defined value from field measurements would meet the demand.

\subsection{CDOM sources}

Negative correlation between salinity and $a_{g}(355)$ (Fig. 5a) suggests that terrestrial inputs were the main source of CDOM in the study area, especially for the riverine end observations with low salinity samples (Fig. 5b). The lower Pearson's coefficient between salinity and $a_{g}(355)$ in high salinity water (> 32 PSU) indicates a weak influence of runoff and a decreased proportion of terrigenous CDOM in the marine end observations. The same conclusion can be drawn from the relationship between salinity and $S_{275-295}$ on one hand, and the dimensionless ratio $S_{\mathrm{R}}$ on the other. The smaller $S_{275-295}$ and $S_{\mathrm{R}}$ are corresponding to the higher MW, which is mostly determined by humic acid from terrestrial sources (Helms et al. 2008). As shown in Fig. 6, the DOM shifted from high MW to low MW with increasing salinity, corresponding to a decreasing proportion of terrigenous CDOM. One important fact is that DOM molecular size was reduced due to photobleaching of terrigenous CDOM during downstream transit, resulting in larger $S_{275-295}$ with increasing salinity (Helms et al. 2008). Additionally, responses of CDOM absorption at $275 \mathrm{~nm}$ and $295 \mathrm{~nm}$ to the exposure to solar radiation are different, where a much greater fractional decrease in $a_{g}(295)$ was found than in $a_{g}(275)$, resulting in a smaller $S_{275-295}$ upstream (Del Vecchio and Blough 2002, 2004; Fichot and Benner 2012). Another factor that determined the high $S_{275-}$ 295 in marine end waters could be attributed to the aquatic CDOM, especially the protein-rich plankton CDOM production, which has been proven to have significant effect on the $S_{275-295}$ (Fichot and Benner 2012).

Compared to the $S_{275-295}$, the $S_{\mathrm{R}}$ seems to be a more effective indicator of the proportion of terrigenous DOM in this study, since the negative relationships between $S_{\mathrm{R}}$ and salinity are more robust for the three types of waters (i.e., riverine-dominant water, mixed water and marine-dominant water) as shown in Fig. 6b. This is mainly due to the fact that the values of the spectral slope $S_{350-400}$ generally decreased with increasing salinity (blue circles in Fig.8), which is consistent with (Helms et al. 2008). The increase of $S_{\mathrm{R}}$ 
is mainly due to the increase of $S_{275-295}$, while the decreasing trend of $S_{350-400}$ enhanced the sensitivity of $S_{\mathrm{R}}$ to terrigenous DOM.

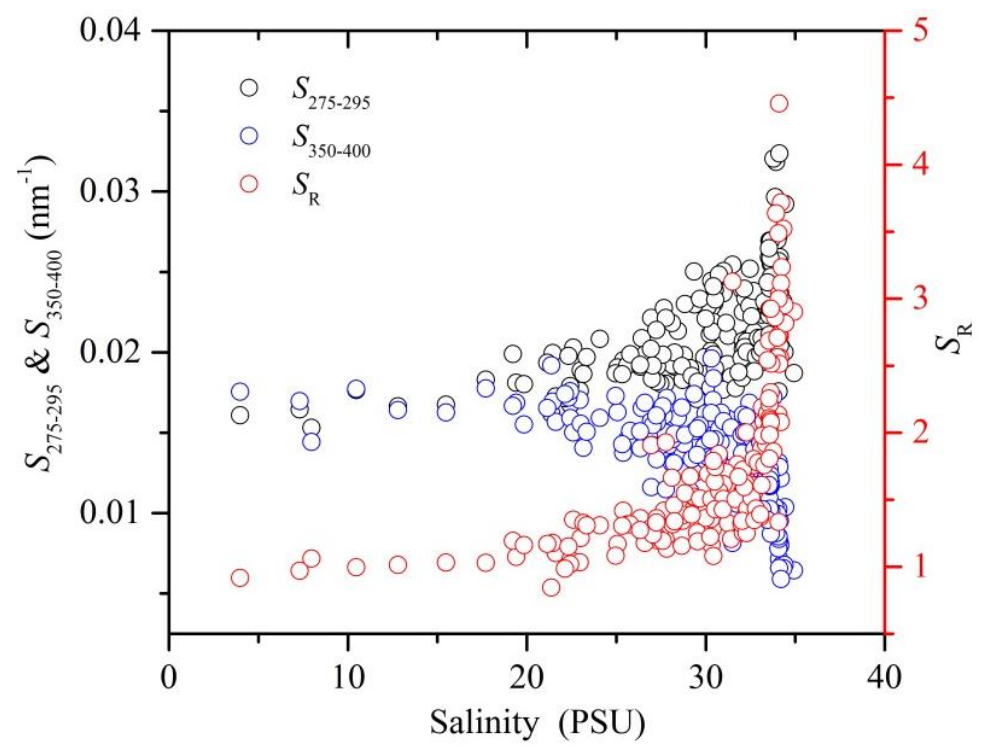

Fig. 8. The trends of the spectral slopes $\left(S_{275-295}\right.$ and $\left.S_{350-400}\right)$ and the slope ratio $S_{\mathrm{R}}$ with increasing salinity.

\subsection{DOC sources and estimation}

The range of DOC concentration in this study (i.e., 60.54 to $217.06 \mu \mathrm{mol} / \mathrm{L}$ ) is comparable with the previous investigations in summer in the Changjiang estuarine and coastal waters with DOC concentration ranging from 139.4 to $220 \mu \mathrm{mol} / \mathrm{L}$ from Zhang et al. (2013). However, our results are higher than the investigations in spring from Sun et al. (2014) with DOC concentration ranging from 41.7 to $126.2 \mu \mathrm{mol} / \mathrm{L}$. The difference between our results and results from Sun et al. (2014) could be firstly attributed to the difference in sampling sites, and secondly due to the larger Changjiang runoff in summer than in spring. On the other hand, DOC concentrations in this study, in agreement with CDOM absorption coefficient, are much lower than in other world's major estuaries. For instance, the DOC concentration in the Amazon River estuary was averaged at $350 \pm 75 \mu \mathrm{mol} / \mathrm{L}$ (Ward et al. 2015), while it reached 446 $\mu \mathrm{mol} / \mathrm{L}$ (Chen and Gardner 2004) and $611 \mu \mathrm{mol} / \mathrm{L}$ (Fichot and Benner 2012) in the Mississippi River estuary, respectively. The DOC concentration even reached as high as $800 \mu \mathrm{mol} / \mathrm{L}$ in the Congo River 
estuary (Spencer et al. 2009b). It is likely that the same factors driving the observed distribution of CDOM result in the relatively low DOC concentrations in the Changjiang estuary.

As shown in Table 1, the mixing behavior between DOC and CDOM in most estuarine and coastal waters is conservative. However, this mixing behavior between the two parameters could be highly variable at seasonal and regional scales. For example, non-conservative mixing between DOC and CDOM can be found in this study, as well as in previous study in the Changjiang estuary (Cauwet and Mackenzie 1993), while a conservative mixing was also reported by Zhang et al. (2013) and Liu et al. (2014). The variation of DOC-CDOM relationship could be attributed to the asynchronous changes between DOC and CDOM (Vodacek et al. 1997). The discrepancy between DOC and CDOM in their stabilities and residence period is always significant in estuarine and coastal waters, because DOC are commonly unstable and easily decomposed compared to the CDOM in coastal waters (Spitzy and Ittekkot 1986). Another factor resulting in the discrepancy could be attributed to phytoplankton production. It seems that DOC and CDOM produced by phytoplankton production is disproportionate, resulting in the collapse of DOC-CDOM correlation in significant phytoplankton production zones (Liu et al. 2013; Liu et al. 2014).

Despite the discrepancy between DOC and CDOM, the developed non-linear model in this study presents a robust method to estimate DOC concentration from $S_{275-295}$ and $a_{g}(355)$ as shown in Fig.7. Note that despite $S_{\mathrm{R}}$ is a more indicative parameter to terrestrial DOM in this study, it seems to be independent to DOC, which is consistent with results from (Helms et al. 2008). The developed model can be considered as satisfactory and the validation result is not biased since the adopted GeoCal/Val model (Salama et al. 2012) ensures that both calibration and validation datasets are independent to each other. Considering the phytoplankton production may result in the discrepancy between DOC and CDOM in this study, the non-linear model developed seems less vulnerable to the effect of phytoplankton production. This, on the other hand, shows that $S_{275-295}$ could be a reliable parameter to estimated DOC concentration in river-influenced estuarine and coastal waters. 
Furthermore, considering the nature of this non-linear relationship is empirical, applying this relationship to different regions could require a fine-tuning on the empirical coefficients. For instance, adopting the empirical coefficients from Fichot and Benner (2012) will overestimate DOC concentration in the Changjiang estuarine and coastal waters as shown in Fig. 7a. On the other hand, as shown in this study, the developed relationship worked well for observations collected from both July 2011 and August 2013, indicating this relationship would be reliable and practical in the summer season in the Changjiang estuarine and coastal waters. Therefore, with the regionally defined DOC-CDOM relationship, DOC concentration can be potentially estimated from earth observation data since the CDOM absorption coefficient can be retrieved from remote sensing reflectance with acceptable accuracy (Lee et al. 2002; Matsuoka et al. 2012b; Siswanto et al. 2011).

\section{Conclusion}

Field measurements on CDOM optical properties and DOC concentration allow the investigation and discussion on the spatial-temporal variation of CDOM and DOC, the sources of CDOM and DOC and their correlations in the Changjiang estuarine and coastal waters. The following conclusions are drawn based on the results presented in this study:

1. CDOM absorption coefficient at $355 \mathrm{~nm}$ was negatively correlated with salinity, resulting in a decreasing gradient of $a_{g}(355)$ from northwest to southeast. The spatial-temporal variation of $a_{g}$ (355) could be highly dependent on the influence of Changjiang runoff. The vertical variation of CDOM was more pronounced in near-shore than that in offshore.

2. The sources of CDOM in the estuary were mainly from terrigenous inputs, while the level of CDOM could be determined by several factors in the drainage basin and the origin of recharged streams. Sediment resuspension could also be an important source of CDOM in winter, while aquatic sources could contribute large proportions of CDOM in marine-dominant waters with high salinities. 
3. A non-linear relationship was developed to estimate DOC concentration from $a_{g}(355)$ and $S_{275-295 \text {, }}$ which was proven to be robust and stable for the Changjiang estuarine and coastal waters. Therefore, the developed relationship provides an alternative approach to estimate DOC at large spatial scales from remotely retrieved CDOM optical properties over the Changjiang estuarine and coastal waters.

\section{Acknowledgements}

This study was supported by the National Science Foundation of China (No.41271375) and the Doctoral Fund of the Ministry of Education of China (No.20120076110009). The authors would like to thank Cui Ying, Zhang Guosen, Zhang Jinfang, Chen Yu, Liu Meng and Peng Xiangyi for their helps with field and laboratory work. The authors are very grateful to Dr. Mhd. Suhyb Salama and Prof. Wouter Verhoef for their constructive comments and help in improving the quality of English writing.

\section{References}

Asmala, E., Stedmon, C.A., \& Thomas, D.N. (2012). Linking CDOM spectral absorption to dissolved organic carbon concentrations and loadings in boreal estuaries. Estuarine Coastal and Shelf Science, $111,107-117$

Astoreca, R., Rousseau, V., \& Lancelot, C. (2009). Coloured dissolved organic matter (CDOM) in Southern North Sea waters: Optical characterization and possible origin. Estuarine Coastal and Shelf Science, 85, 633-640

Baker, A., \& Spencer, R.G. (2004). Characterization of dissolved organic matter from source to sea using fluorescence and absorbance spectroscopy. Science of the total environment, 333, 217-232

Bodineau, L., Thoumelin, G., Beghin, V., \& Wartel, M. (1998). Tidal time-scale changes in the composition of particulate organic matter within the estuarine turbidity maximum zone in the macrotidal Seine estuary, France: the use of fatty acid and sterol biomarkers. Estuarine, Coastal and Shelf Science, 47, 37-49

Bricaud, A., Morel, A., \& Prieur, L. (1981). Absorption by Dissolved Organic-Matter of the Sea (Yellow Substance) in the Uv and Visible Domains. Limnology and Oceanography, 26, 43-53

Carder, K.L., Steward, R.G., Harvey, G.R., \& Ortner, P.B. (1989). Marine Humic and Fulvic-Acids Their Effects on Remote-Sensing of Ocean Chlorophyll. Limnology and Oceanography, 34, 68-81 
Cauwet, G., \& Mackenzie, F.T. (1993). Carbon inputs and distribution in estuaries of turbid rivers: the Yang Tze and Yellow rivers (China). Marine Chemistry, 43, 235-246

Chen, R.F., \& Gardner, G.B. (2004). High-resolution measurements of chromophoric dissolved organic matter in the Mississippi and Atchafalaya River plume regions. Marine Chemistry, 89, 103-125

Chen, S.L., Zhang, G.A., \& Yang, S.L. (2003). Temporal and spatial changes of suspended sediment concentration and resuspension in the Yangtze River estuary. Journal of Geographical Sciences, 13, 498-506

Chen, Z.Q., Li, Y., \& Pan, J.M. (2004). Distributions of colored dissolved organic matter and dissolved organic carbon in the Pearl River Estuary, China. Continental Shelf Research, 24, 1845-1856

Del Castillo, C.E., Coble, P.G., Morell, J.M., L O Pez, J.M., \& Corredor, J.E. (1999). Analysis of the optical properties of the Orinoco River plume by absorption and fluorescence spectroscopy. Marine Chemistry, 66, 35--51

Del Castillo, C.E., Gilbes, F., Coble, P.G., \& Müller-Karger, F.E. (2000). On the dispersal of riverine colored dissolved organic matter over the West Florida Shelf. Limnology and Oceanography, 45, 14251432

Del Castillo, C.E., \& Miller, R.L. (2011). Horizontal and vertical distributions of colored dissolved organic matter during the Southern Ocean Gas Exchange Experiment. Journal of Geophysical Research, 116, C00F07

Del Vecchio, R., \& Blough, N.V. (2002). Photobleaching of chromophoric dissolved organic matter in natural waters: kinetics and modeling. Marine Chemistry, 78, 231-253

Del Vecchio, R., \& Blough, N.V. (2004). On the origin of the optical properties of humic substances. Environmental Science \& Technology, 38, 3885-3891

Ferrari, G.M. (2000). The relationship between chromophoric dissolved organic matter and dissolved organic carbon in the European Atlantic coastal area and in the West Mediterranean Sea (Gulf of Lions). Marine Chemistry, 70, 339-357

Fichot, C.G., \& Benner, R. (2011). A novel method to estimate DOC concentrations from CDOM absorption coefficients in coastal waters. Geophysical Research Letters, 38, L03610

Fichot, C.G., \& Benner, R. (2012). The spectral slope coefficient of chromophoric dissolved organic matter (S275-295) as a tracer of terrigenous dissolved organic carbon in river-influenced ocean margins. Limnology and Oceanography, 57, 1453-1466

Gardner, G.B., Chen, R.F., \& Berry, A. (2005). High-resolution measurements of chromophoric dissolved organic matter (CDOM) in the Neponset River Estuary, Boston Harbor, MA. Marine Chemistry, 96, $137-154$ 
Garver, S.A., \& Siegel, D.A. (1997). Inherent optical property inversion of ocean color spectra and its biogeochemical interpretation .1. Time series from the Sargasso Sea. Journal of Geophysical ResearchOceans, 102, 18607-18625

Granskog, M.A. (2012). Changes in spectral slopes of colored dissolved organic matter absorption with mixing and removal in a terrestrially dominated marine system (Hudson Bay, Canada). Marine Chemistry, 134-135, 10-17

Green, S.A., \& Blough, N.V. (1994). Optical-Absorption and Fluorescence Properties of Chromophoric Dissolved Organic-Matter in Natural-Waters. Limnology and Oceanography, 39, 1903-1916

Guo, W.D., Stedmon, C.A., Han, Y.C., Wu, F., Yu, X.X., \& Hu, M.H. (2007). The conservative and nonconservative behavior of chromophoric dissolved organic matter in Chinese estuarine waters. Marine Chemistry, 107, 357-366

Guo, W.D., Yang, L.Y., Zhai, W.D., Chen, W.Z., Osburn, C.L., Huang, X., \& Li, Y. (2014). Runoff mediated seasonal oscillation in the dynamics of dissolved organic matter in different branches of a large bifurcated estuary-The Changjiang Estuary. Journal of Geophysical Research: Biogeosciences, $119,776-793$

Hansell, D.A., \& Carlson, C.A. (1998). Deep-ocean gradients in the concentration of dissolved organic carbon. Nature, 395, 263-266

Helms, J.R., Stubbins, A., Ritchie, J.D., Minor, E.C., Kieber, D.J., \& Mopper, K. (2008). Absorption spectral slopes and slope ratios as indicators of molecular weight, source, and photobleaching of chromophoric dissolved organic matter. Limnology and Oceanography, 53, 955-969

Hong, H.S., Wu, J.Y., Shang, S.L., \& Hu, C.M. (2005). Absorption and fluorescence of chromophoric dissolved organic matter in the Pearl River Estuary, South China. Marine Chemistry, 97, 78-89

Huang, Y., Salama, M., Krol, M.S., Su, Z., Hoekstra, A.Y., Zeng, Y., \& Zhou, Y. (2015). Estimation of human-induced changes in terrestrial water storage through integration of GRACE satellite detection and hydrological modeling: A case study of the Yangtze River basin. Water Resources Research, 51, 8494-8516

Huang, Y., Salama, M.S., Su, Z., van der Velde, R., Zheng, D., Krol, M.S., Hoekstra, A.Y., \& Zhou, Y. (2016). Effects of Roughness Length Parameterizations on Regional-Scale Land Surface Modeling of Alpine Grasslands in the Yangtze River Basin. Journal of Hydrometeorology, 17, 1069-1085

Keith, D.J., Yoder, J.A., \& Freeman, S.A. (2002). Spatial and temporal distribution of coloured dissolved organic matter (CDOM) in Narragansett Bay, Rhode Island: Implications for phytoplankton in coastal waters. Estuarine, Coastal and Shelf Science, 55, 705-717

Kuliński, K., \& Pempkowiak, J. (2008). Dissolved organic carbon in the southern Baltic Sea: Quantification of factors affecting its distribution. Estuarine, Coastal and Shelf Science, 78, 38-44

Lagerloef, G.S., Swift, C.T., \& Le Vine, D.M. (1995). Sea surface salinity: The next remote sensing challenge. National Aeronautics and Space Administration 
Lee, Z., Weidemann, A., Kindle, J., Arnone, R., Carder, K.L., \& Davis, C. (2007). Euphotic zone depth: Its derivation and implication to ocean-color remote sensing. Journal of Geophysical ResearchOceans, 112, C03009

Lee, Z.P., Carder, K.L., \& Arnone, R.A. (2002). Deriving inherent optical properties from water color: a multiband quasi-analytical algorithm for optically deep waters. Applied Optics, 41, 5755--5772

Lei, H., Pan, D.L., Bai, Y., Tao, B.Y., Sun, J., Zhang, L., \& Zhang, X. (2012). The proportions and variations of the light absorption coefficients of major ocean color components in the East China Sea. ACTA Oceanologica Sinica, 31, 45-61

Liu, Q., Pan, D., Bai, Y., Wu, K., Chen, C.-T.A., Sun, J., \& Zhang, L. (2013). The satellite reversion of dissolved organic carbon (DOC) based on the analysis of the mixing behavior of DOC and colored dissolved organic matter: the East China Sea as an example. ACTA Oceanologica Sinica, 32, 1-11

Liu, Q., Pan, D.L., Bai, Y., Wu, K., Chen, C.T.A., Liu, Z.L., \& Zhang, L. (2014). Estimating dissolved organic carbon inventories in the East China Sea using remote-sensing data. Journal of Geophysical Research-Oceans, 119, 6557-6574

Longhurst, A.R., \& Harrison, W.G. (1989). The Biological Pump - Profiles of Plankton Production and Consumption in the Upper Ocean. Progress in Oceanography, 22, 47-123

Ludwig, W., Probst, J.L., \& Kempe, S. (1996). Predicting the oceanic input of organic carbon by continental erosion. Global Biogeochemical Cycles, 10, 23-41

Mannino, A., Russ, M.E., \& Hooker, S.B. (2008). Algorithm development and validation for satellitederived distributions of DOC and CDOM in the US Middle Atlantic Bight. Journal of Geophysical Research-Oceans, 113, C07051

Maritorena, S., Siegel, D.A., \& Peterson, A.R. (2002). Optimization of a semianalytical ocean color model for global-scale applications. Applied Optics, 41, 2705--2714

Matsuoka, A., Bricaud, A., Benner, R., Para, J., Sempere, R., Prieur, L., Belanger, S., \& Babin, M. (2012a). Tracing the transport of colored dissolved organic matter in water masses of the Southern Beaufort Sea: relationship with hydrographic characteristics. Biogeosciences, 9, 925-940

Matsuoka, A., Hooker, S.B., Bricaud, A., Gentili, B., \& Babin, M. (2012b). Estimating absorption coefficients of colored dissolved organic matter (CDOM) using a semi-analytical algorithm for Southern Beaufort Sea (Canadian Arctic) waters: application to deriving concentrations of dissolved organic carbon from space. Biogeosciences Discussions, 9, 13743--13771

Nieke, B., Reuter, R., Heuermann, R., Wang, H., Babin, M., \& Therriault, J.C. (1997). Light absorption and fluorescence properties of chromophoric dissolved organic matter (CDOM), in the St Lawrence Estuary (Case 2 waters). Continental Shelf Research, 17, 235-252

Pan, D., Liu, Q., \& Bai, Y. (2012). Progress in remote sensing of DOC:based on the analysis of conservative behaviors of DOC and CDOM in globla rivers estuaries. ACTA Oceanologica Sinica, 34, 1-11 (In Chinese with English abstract) 
Pegau, W.S., Gray, D., \& Zaneveld, J.R.V. (1997). Absorption and attenuation of visible and near-infrared light in water: dependence on temperature and salinity. Applied Optics, 36, 6035-6046

Retamal, L., Vincent, W.F., Martineau, C., \& Osburn, C.L. (2007). Comparison of the optical properties of dissolved organic matter in two river-influenced coastal regions of the Canadian Arctic. Estuarine Coastal and Shelf Science, 72, 261-272

Rochelle-Newall, E., Hulot, F.D., Janeau, J.L., \& Merroune, A. (2014). CDOM fluorescence as a proxy of DOC concentration in natural waters: a comparison of four contrasting tropical systems. Environmental Monitoring and Assessment, 186, 589-596

Rochelle-Newall, E.J., \& Fisher, T.R. (2002). Chromophoric dissolved organic matter and dissolved organic carbon in Chesapeake Bay. Marine Chemistry, 77, 23-41

Salama, M.S., Van der Velde, R., van der Woerd, H.J., Kromkamp, J.C., Philippart, C.J.M., Joseph, A.T., O'Neill, P.E., Lang, R.H., Gish, T., Werdell, P.J., \& Su, Z. (2012). Technical Note: Calibration and validation of geophysical observation models. Biogeosciences, 9, 2195-2201

Siswanto, E., Tang, J.W., Yamaguchi, H., Ahn, Y.H., Ishizaka, J., Yoo, S., Kim, S.W., Kiyomoto, Y., Yamada, K., Chiang, C., \& Kawamura, H. (2011). Empirical ocean-color algorithms to retrieve chlorophyll-a, total suspended matter, and colored dissolved organic matter absorption coefficient in the Yellow and East China Seas. Journal of oceanography, 67, 627-650

Spencer, R.G.M., Ahad, J.M.E., Baker, A., Cowie, G.L., Ganeshram, R., Upstill-Goddard, R.C., \& Uher, G. (2007). The estuarine mixing behaviour of peatland derived dissolved organic carbon and its relationship to chromophoric dissolved organic matter in two North Sea estuaries (UK). Estuarine Coastal and Shelf Science, 74, 131-144

Spencer, R.G.M., Aiken, G.R., Butler, K.D., Dornblaser, M.M., Striegl, R.G., \& Hernes, P.J. (2009a). Utilizing chromophoric dissolved organic matter measurements to derive export and reactivity of dissolved organic carbon exported to the Arctic Ocean: A case study of the Yukon River, Alaska. Geophysical Research Letters, 36, L06401

Spencer, R.G.M., Stubbins, A., Hernes, P.J., Baker, A., Mopper, K., Aufdenkampe, A.K., Dyda, R.Y., Mwamba, V.L., Mangangu, A.M., Wabakanghanzi, J.N., \& Six, J. (2009b). Photochemical degradation of dissolved organic matter and dissolved lignin phenols from the Congo River. Journal of Geophysical Research-Biogeosciences, 114, G03010

Spitzy, A., \& Ittekkot, V. (1986). Gelbstoff: an uncharacterized fraction of dissolved organic carbon. The Influence of Yellow Substances on Remote Sensing of Sea-Water Constituent From Space

Sun, Q., Wang, C., Wang, P., Hou, J., \& Ao, Y. (2014). Absorption and fluorescence characteristics of chromophoric dissolved organic matter in the Yangtze Estuary. Environmental Science and Pollution Research, 21, 3460-3473

Vodacek, A., Blough, N.V., DeGrandpre, M.D., Peltzer, E.T., \& Nelson, R.K. (1997). Seasonal variation of CDOM and DOC in the Middle Atlantic Bight: Terrestrial inputs and photooxidation. Limnology and Oceanography, 42, 674-686 
Ward, N.D., Krusche, A.V., Sawakuchi, H.O., Brito, D.C., Cunha, A.C., Moura, J.M.S., da Silva, R., Yager, P.L., Keil, R.G., \& Richey, J.E. (2015). The compositional evolution of dissolved and particulate organic matter along the lower Amazon River-Óbidos to the ocean. Marine Chemistry, $177,244-256$

Warnock, R.E., Gieskes, W.W.C., \& van Laar, S. (1999). Regional and seasonal differences in light absorption by yellow substance in the Southern Bight of the North Sea. Journal of Sea Research, 42, $169-178$

Xie, H.X., Aubry, C., Belanger, S., \& Song, G.S. (2012). The dynamics of absorption coefficients of CDOM and particles in the St. Lawrence estuarine system: Biogeochemical and physical implications. Marine Chemistry, 128, 44-56

Yang, W., Matsushita, B., Chen, J., Yoshimura, K., \& Fukushima, T. (2013). Retrieval of inherent optical properties for turbid inland waters from remote-sensing reflectance. Ieee Transactions on Geoscience and Remote Sensing, 51, 3761-3773

Yu, X., Salama, M.S., Shen, F., \& Verhoef, W. (2016). Retrieval of the diffuse attenuation coefficient from GOCI images using the 2SeaColor model: A case study in the Yangtze Estuary. Remote Sensing of Environment, 175, 109-119

Zhang, X.Y., Chen, X., Deng, H., Du, Y., \& Jin, H.Y. (2013). Absorption features of chromophoric dissolved organic matter (CDOM) and tracing implication for dissolved organic carbon (DOC) in Changjiang Estuary, China. Biogeosciences Discussions, 10, 12217--12250 